\title{
Risk Factors and Outcome in Patients with Severe Acute Asthma Requiring Mechanical Ventilation
}

\author{
B.O. Onadeko ${ }^{a}$ M.E. Khadadah ${ }^{a}$ H.T. Mustafa ${ }^{\text {b }}$ K.E.H. Metwalic \\ aDepartment of Medicine, Faculty of Medicine, Kuwait University, and Departments of \\ ${ }^{b}$ Medicine and ${ }^{\mathrm{c}}$ Anaesthesia, Mubarak Al-Kabeer Hospital, Kuwait
}

\section{Key Words}

Severe acute asthma $\cdot$ Intensive care unit . Mechanical ventilation

\begin{abstract}
Objective: Severe acute asthma has been recognized as a cause of significant morbidity and mortality. Mechanical ventilation may be necessary to support life in the most critically ill patients. In this study, we set out to identify factors which may affect the outcome of management in severe acute asthma. Methods: Patients with severe acute asthma admitted to the intensive care unit of the Mubarak Al-Kabeer Hospital, Kuwait, over a 2-year period (1996 and 1997) were recruited for the study. The clinical features at presentation, drug treatment and the type of ventilation used, the duration of ventilation and the outcome were monitored. $\mathrm{PaCO}_{2}, \mathrm{pH}$, and ventilation parameters were monitored. Results: Thirty patients selected
\end{abstract}

\begin{tabular}{ll}
\hline KARGER & (1) 1999 S. Karger AG, Basel \\
Fax +41 61 306 1234 34 & \\
$\begin{array}{l}\text { E-Mail karger@karger.ch } \\
\text { www.karger.com }\end{array}$ & $\begin{array}{l}\text { Accessible online at: } \\
\text { http://BioMedNet.com/karger }\end{array}$
\end{tabular}

from a total of 36 patients admitted to the intensive care unit with diagnosis of severe acute asthma were studied. Twenty-one $(70 \%)$ of these patients were mechanically ventilated. The duration of ventilation, and the duration in the intensive care unit for the patients who developed complications and for those who did not were found to be significant ( $p<0.02$ and $p<0.01$, respectively). There was no statistical difference in patients with or without complications in the following parameters at presentation: pulse rate, respiratory rate, $\mathrm{pH}, \mathrm{PaCO}_{2}$, duration of onset of symptoms, peak airway pressure, minute ventilation, tidal volume, and fraction of inspired oxygen. Two (9.5\%) patients died. Factors found to affect outcome include duration of intubation, duration in intensive care unit and pulse rate at presentation. Conclusion: This study revealed that mechanical ventilation is effective and safe in management when it is critically applied and monitored.
Prof. B.O. Onadeko

Department of Medicine, Faculty of Medicine

Kuwait University, PO Box 24923

Safat 13110 (Kuwait)

Tel. +9655319596 


\section{Introduction}

Severe acute asthma has been recognized as a cause of significant morbidity and mortality [1-6]. Prompt and appropriate therapy has been observed to improve survival $[4,5$, 7]. Mechanical ventilation may be necessary to support life in the most severely ill patients. However, not all patients who have hypercapnia will need to be mechanically ventilated [8-11].

Recent studies have suggested that mechanical ventilation may itself be a major cause of most of the morbidity and mortality [12-15]. Studies have shown that patients who required ventilation had mortality rates varying from 0 to $38 \%$. Complications which have been reported included cardiac arrhythmia, barotrauma and hypotension. Risk factors for complications and mortality in these patients have been documented in some studies $[6,9,16,17]$.

Due attention has been given to the management of severe acute asthma in the economically developed world. Asthma is also a common clinical problem in many developing countries. Very little information is available on the clinicopathological features, management and outcome of asthma in these areas. Recently, Lee et al. [18] reported their experience on the management of severe acute asth$\mathrm{ma}$ in Singapore over a 6-year period.

The management of asthma and its exacerbation has improved in recent years in $\mathrm{Ku}$ wait, due to the provision of modern facilities in the emergency rooms and the intensive care units (ICU) of the tertiary hospitals. We therefore report our experience over the last 2 years (1996-1997) on the management of severe acute asthma in the ICU by mechanical ventilation, identifying the factors that influence the outcome in these patients.

\section{Patients and Methods}

Patients with severe acute asthma, admitted to the ICU of the teaching hospital Mubarak Al-Kabeer for mechanical ventilation over a 2-year period, were included in the study. All cases fulfilled the criteria for the diagnosis of bronchial asthma as specified by the American Thoracic Society [19]. Patients who were jointly managed by the staff of the ICU and the respiratory unit were prospectively studied. Cases which on investigation turned out to be chronic obstructive pulmonary disease were excluded from the analysis.

The data recorded included the duration of asthma, duration of the onset of acute symptoms before reporting to the hospital, history of previous admission to the hospital in acute exacerbation, previous medication including maintenance corticosteroid therapy, indication for ventilation and duration in the ICU and hospital.

Mechanical ventilation was carried out using the volume-cycled servo 900 ventilator. Low volume hypercapnic ventilatory support was adopted. Ventilation was initially started with continuous mandatory ventilation and adjusted as necessary by continuous monitoring of peak airway pressure (PIP) and respiratory rate. The respiratory rate is controlled by monitoring clinically the duration of expiratory wheeze. Tidal volume $\left(\mathrm{V}_{\mathrm{T}}\right)$ is adjusted depending on the PIP. Adjustment of ventilation during treatment is guided by PIP and blood gas estimations. The objective is to maintain a state of PIP to avoid lung barotrauma and reduce $\mathrm{PaCO}_{2}$ gradually over several hours. Muscle relaxant and sedatives were given at the start of ventilation. This consists of vecuronium $4 \mathrm{mg} / \mathrm{kg} / \mathrm{h}$ and isopropylphenol $0.5-3 \mathrm{mg} / \mathrm{kg} / \mathrm{h}$, the dose being varied according to response.

The fraction of inspired oxygen $\left(\mathrm{FiO}_{2}\right)$ was adjusted according to the degree of hypoxaemia. The aim is to achieve arterial oxygen saturation of at least $92 \%$. The drugs were discontinued when clinical response was observed, the muscle relaxant first, followed by the sedative. The patients were 'weaned' from the ventilator when they became awake. Arterial blood gas analysis was done at presentation and at regular intervals as required. Other investigations done included complete blood count, chest radiograph, peak expiratory flow rate, electrocardiography and serum electrolytes, urea, and creatinine.

Hypercapnia was defined as $\mathrm{PaCO}_{2} \geq 5.8 \mathrm{kPa}$ $\left(45 \mathrm{~mm} \mathrm{Hg}\right.$ ), and respiratory failure as $\mathrm{PaCO}_{2}>6.4$ $\mathrm{kPa}(50 \mathrm{~mm} \mathrm{Hg})$ [8]. Monitoring of patients either continuously, or at regular intervals was carried out for parameters such as electrocardiograph, blood pressure, 
central venous pressure, pulse oxymetry and fluid balance.

All patients were treated with systemic hydrocortisone (100-200 mg) 6-hourly, salbutamol and ipratropium bromide by nebulizer. Aminophylline $(0.5 \mathrm{mg} /$ $\mathrm{kg} / \mathrm{h}$ ) by continuous intravenous infusion was added when the bronchospasm was not adequately relieved by the bronchodilators. Oxygen was administered continuously using $\mathrm{FiO}_{2}, 0.45-0.6$.

For statistical comparison, $t$ test for equality of means was used. Results were presented as mean \pm SD and $p<0.05$ was accepted as statistically significant.

\section{Results}

Thirty-six patients were admitted as cases of severe acute asthma, but 30 were eventually included in the study. The remaining 6 turned out to be cases of chronic obstructive pulmonary disease and were excluded. Twenty-one of the 30 were treated with mechanical ventilation.

Table 1 gives the summary of clinical and ventilatory parameters of the patients. There were 7 males and 14 females, aged between 13 and 70 years, with a mean of $44.8 \pm 17.4$. The duration of onset of acute symptoms before presentation at the hospital varied from 1 to 3 days, with more than $50 \%$ presenting to the hospital within 1 day of onset of the symptoms. The indications for ventilation were coma in 8 patients, drowsiness with severe hypoxaemia in 3 , severe hypercapnia and restlessness in 6 , and muscle fatigue with exhaustion in 4.

Nineteen $(90 \%)$ of the 21 patients had hypercapnia at presentation. Two of the patients who had normal $\mathrm{PaCO}_{2}$ level were ventilated because of marked hypoxaemia.

The duration of stay in the ICU varied from 1 to 23 days, with a mean of $6.8 \pm 5.1$, while the duration in the hospital varied from 3 to 26 days, with a mean of $12.6 \pm 7.3$.
Table 1. Summary of overall clinical and ventilatory parameters in patients with severe acute asthma requiring mechanical ventilation at presentation

\begin{tabular}{|c|c|}
\hline Variables & $\begin{array}{l}\text { Values expressed } \\
\text { as mean } \pm \mathrm{SD}\end{array}$ \\
\hline Age, years & $44.8 \pm 17.4$ \\
\hline $\begin{array}{l}\text { Duration of onset of symptoms, } \\
\text { days }\end{array}$ & $1.44 \pm \quad 0.81$ \\
\hline $\begin{array}{l}\text { Duration of intubation and } \\
\text { ventilation, days }\end{array}$ & $5.63 \pm 3.2$ \\
\hline Duration in ICU & $6.5 \pm 5.1$ \\
\hline Duration in hospital & $12.6 \pm 7.3$ \\
\hline $\mathrm{pH}$ & $7.15 \pm \quad 0.2$ \\
\hline $\mathrm{PaCO}_{2}$ & $9.2 \pm 3.5$ \\
\hline Pulse rate at presentation & $132 \pm 12.3$ \\
\hline $\mathrm{WBC}$ at presentation & $15.3 \times 10^{9} / 1 \pm 6.0$ \\
\hline Blood pressure & \\
\hline Systolic & $146 \pm 33.8$ \\
\hline Diastolic & $85.9 \pm 20.6$ \\
\hline $\mathrm{FiO}_{2}$ & $0.49 \pm \quad 0.1$ \\
\hline $\mathrm{V}_{\mathrm{T}}, \mathrm{ml}$ & $562 \pm 174.2$ \\
\hline $\mathrm{V}_{\mathrm{E}}$, litres & $7.59 \pm \quad 1.5$ \\
\hline $\mathrm{PIP}, \mathrm{cm} \cdot \mathrm{H}_{2} \mathrm{O}$ & $36.2 \pm 11.9$ \\
\hline Respiratory rate on ventilator & $16.4 \pm 3.3$ \\
\hline
\end{tabular}

Twelve (53\%) of the 21 patients gave a history of previous admission to the ICU and hospital during the current admission. Four (19\%) of these patients subsequently had complications following ventilation. Six of the 21 patients were known to be steroid-dependent. Arterial blood gases at presentation revealed a $\mathrm{PaCO}_{2}$ level which ranged from 5.2 to $14.4 \mathrm{kPa}$, with a mean of $9.2 \pm 3.5$. Blood $\mathrm{pH}$ varied from 6.79 to 7.4 , with a mean of $7.15 \pm 0.2$.

Cyanosis at presentation occurred in 15 of the patients. The most commonly encountered precipitating factor is respiratory tract infection, occurring in 15 of the 21 patients. Apart from clinical features which suggested infection, the white cell count was greater than $12 \times 10^{9} / 1$ (leucocytosis). The organism 
Table 2. Complications encountered in mechanically ventilated patients with severe acute asthma

\begin{tabular}{lc}
\hline Complication & $\begin{array}{l}\text { Cases } \\
\mathrm{n}\end{array}$ \\
\hline Consolidation & 1 \\
Lung collapse & 4 \\
Cardiac arrhythmia $^{\text {Myocardial infarction and hypotension }}{ }^{1}$ & 2 \\
Hemiplegia and hypotension $^{\text {Sepsis syndrome and brain infarcts }}{ }^{1}$ & 1 \\
\hline Total & 1 \\
\hline
\end{tabular}

1 Died. was cultured in the sputum/broncho-alveolar lavage in only 6 patients. Viral studies were not done. Antibiotics, mainly erythromycin and amoxicillin, were empirically given to the patients. In 8 patients, third-generation cephalosporin was added either because of the result of the sensitivity report or because of the severity of the infection. Complications during the course of management were recorded in 10 of the patients. These are illustrated in table 2 . Two patients died, giving a mortality rate of $9.5 \%$. These patients were in the group which developed complications. The cause of death was due to disseminated

Table 3. Comparison of clinical and ventilatory parameters in patients with and without complications who underwent mechanical ventilation

\begin{tabular}{|c|c|c|c|}
\hline Variables $^{1}$ & $\begin{array}{l}\text { Patients with } \\
\text { complications } \\
(\mathrm{n}=10)\end{array}$ & $\begin{array}{l}\text { Patients with no } \\
\text { complications } \\
(\mathrm{n}=11)\end{array}$ & $\mathrm{p}$ value \\
\hline Age, years & $47.7 \pm 17$ & $43.2 \pm 16.9$ & $0.55(\mathrm{NS})$ \\
\hline Duration of onset of symptoms & $1.44 \pm 0.8$ & $1.43 \pm \quad 0.7$ & $0.47(\mathrm{NS})$ \\
\hline Duration of ventilation, days & $6.5 \pm 2.73$ & $3.55 \pm$ & $<0.01(\mathrm{~S})$ \\
\hline Duration in ICU, days & $9.1 \pm 6.03$ & $4 \pm$ & $<0.01(\mathrm{~S})$ \\
\hline Duration in hospital & $14.7 \pm 8.69$ & $9.36 \pm 2.84$ & $0.09(\mathrm{NS})$ \\
\hline $\mathrm{pH}$ & $7.13 \pm 0.21$ & $7.18 \pm$ & $0.5(\mathrm{NS})$ \\
\hline $\mathrm{PaCO}_{2}$ & $10.2 \pm 3.51$ & $8.76 \pm \quad 4.05$ & 0.4 (NS) \\
\hline Pulse rate at presentation & $138 \pm 11.6$ & $127 \pm 11.4$ & $0.08(\mathrm{NS})$ \\
\hline WBC at presentation & $16.8 \times 10^{9} / 1 \pm 8.55$ & $14.2 \times 10^{9} / 1 \pm 3.42$ & 0.6 (NS) \\
\hline \multicolumn{4}{|l|}{ Blood pressure } \\
\hline Systolic & $145 \pm 31.4$ & $\pm \quad 4.2$ & $0.3(\mathrm{NS})$ \\
\hline Diastolic & $94 \pm 18.4$ & $78 \pm 21.8$ & $0.10(\mathrm{NS})$ \\
\hline $\mathrm{FiO}_{2}$ & $0.53 \pm 0.3$ & $0.48 \pm \quad 0.11$ & 0.5 (NS) \\
\hline $\mathrm{V}_{\mathrm{T}}, \mathrm{ml} / \mathrm{kg}$ & $512 \pm 14.8$ & $590 \pm 192$ & $0.4(\mathrm{NS})$ \\
\hline $\mathrm{V}_{\mathrm{E}}$, litres/min & $7.45 \pm 2.44$ & $7.66 \pm 0.99$ & 0.8 (NS) \\
\hline $\mathrm{PIP}, \mathrm{cm} \mathrm{H}_{2} \mathrm{O}$ & $27.3 \pm 12.5$ & $40.1 \pm 10.2$ & 0.2 (NS) \\
\hline Respiratory rate on ventilator & $14.3 \pm 0.5$ & $14.9 \pm 4.3$ & $0.7 \quad(\mathrm{NS})$ \\
\hline
\end{tabular}

NS = Not significant $\mathrm{S}=$ significant.

1 Values expressed as mean $\pm \mathrm{SD}$. 
intravascular coagulopathy from septic shock syndrome in 1 , and prolonged hypotension from myocardial infarction in the other. The 4 patients with lung collapse due to mucous impaction improved after bronchoscopy. Other complications were successfully treated.

Table 3 shows the comparison between clinical and ventilatory parameters in patients who developed complications and those who did not. There is a statistically significant difference in the duration of ventilation $(\mathrm{p}<$ $0.01)$ and in the duration of stay in the ICU $(p<0.01)$. No significant difference was observed between the two groups concerning the age, duration in hospital, $\mathrm{pH}, \mathrm{PaCO}_{2}$, heart rate and white blood cell count at presentation.

The ventilatory parameters employed during ventilation were not observed to be directly related to the development of complications. $\mathrm{FiO}_{2}, \mathrm{~V}_{\mathrm{T}}, \mathrm{V}_{\mathrm{E}}$, respiratory rate, and PIP were not significantly different in patients who had complications and those who did not.

\section{Discussion}

The results from this study have shown that basic clinical characteristics of the patients such as age, sex, and duration of asthma are not significantly different from those reported in other series $[3,6,8,18,20]$. In this study, coma, drowsiness, restlessness and fatigue are the most important indications for mechanical ventilation. A similar observation was made by Lee et al. [18] in Singapore, and Braman and Kaemmerlen [8]. It has been reported in earlier studies that mechanical ventilation in severe acute asthma is frequently associated with complications $[3,4,9,17]$. In this study, complications were encountered in 37\% of the patients. Known complications reported in previous studies included barotrauma (pneumothorax and pneumomediastinum), cardiac arrhythmias, hypotension, consolidation and collapse.

We did not encounter any case of pneumothorax in our series. A similar observation has been reported in the series of Williams et al. [16] and Lee et al. [18]. The reason for this observation may be related to the availability in the last few years of modern volume-cycled ventilators, which make feasible the monitoring and adjustment of ventilatory parameters.

The mortality in this series was $9.5 \%$. This is comparable with the rates in the other studies as shown in table 4. However, in some studies no mortality was reported in asthma patients treated with mechanical ventilation [8, 9, 14, 21]. Williams et al. [16] concluded from their own findings that it may be possible to minimize complications and death by using a pattern of mechanical ventilation that maintains a low $\mathrm{V}_{\mathrm{E}}, \mathrm{V}_{\mathrm{T}}$ of 8-10 $\mathrm{ml}$ and respiratory rate of $11-14$ breaths $/ \mathrm{min}$.

In this study, it was observed that the duration of ventilation and the duration in the ICU showed statistically significant difference between those patients who developed complications and those who did not. However, when other factors such as duration of onset of symptoms before presentation to hospital, $\mathrm{pH}$, $\mathrm{PaCO}_{2}$, heart rate and blood pressure were examined, there was no significant difference statistically in the two groups of patients. Similarly, no statistically significant difference between the two groups was found in the ventilatory parameters such as $\mathrm{FiO}_{2}, \mathrm{~V}_{\mathrm{T}}, \mathrm{V}_{\mathrm{E}}$, and PIP. These observations were also noted in the study of Williams et al. [16]. Furthermore, factors, such as previous hospitalization and intubation, steroid-dependent state, and duration of history of asthma were observed in this study, and hence considered to be insignificant between the two groups. 
Table 4. Comparison of mortality rates in patients treated with mechanical ventilation in published reports and this study

\begin{tabular}{lllc}
\hline Authors & $\begin{array}{l}\text { Patients } \\
\text { ventilated } \\
\text { n }\end{array}$ & Deaths & Mortality \\
& & $\%$ \\
\hline Darioli and Perret [14] & 34 & 0 & 0 \\
Marchand and Van Hesselt [25] & 14 & 3 & 21 \\
Williams and Crooke [24] & 18 & 2 & 11 \\
Westerman et al. [6] & 39 & 4 & 10 \\
Scoggin et al. [5] & 21 & 6 & 38 \\
Luksza et al. [4] & 32 & 3 & 9 \\
Braman and Kaemmerlen [8] & 64 & 0 & 0 \\
Lee et al. [18] & 30 & 6 & 2 \\
Lim [10] & 19 & 2 & 11 \\
Picado et al. [3] & 26 & 6 & 23 \\
Present study & 21 & 2 & 9.5 \\
& & &
\end{tabular}

The duration of onset of acute symptoms was short, with more than $50 \%$ of the patients presenting within $24 \mathrm{~h}$. Only 3 patients presented 3 days after the onset of symptoms, 2 of which subsequently developed complications. In contrast, in the series by Luksza et al. [4], the onset of symptoms evolved over days rather than hours in $86 \%$ of the patients. The reason for early presentation to the hospital by patients after the onset of acute symptoms in our study could be due to easy accessibility to medical care in the hospital, but it could also possibly be due to increased awareness of the patients and/or their relatives of the potential danger of development of a fatal attack. It could also be related to the patients' experience of previous episodes of severe attacks and management with intubation and mechanical ventilation. In fact, $43 \%$ of the patients in this series gave a history of previous hospitalization and management with artificial ventilation. This finding has also been reported in other series [19, 22, 23].

The determining factor to the improved outcome of management of severe acute asthma in this study is due to the increasing awareness of patients of their disease and their prompt response to seek medical attention. Shorter duration of ventilation and short duration of stay in the ICU and fewer complications are also recognized factors contributing to better outcome. Furthermore, the availability of adequate medical facilities including modern ventilators and trained health personnel are favourable contributing factors.

In conclusion, this study has revealed that mechanical ventilation can be safely utilized in the care of patients presenting with severe acute asthma, with minimal or no morbidity and mortality.

\section{Acknowledgments}

We are grateful to Dr. T. Sugathan, statistician of the Department of Community Medicine, Kuwait University, for his statistical advice. We are also indebted to Mrs. Haider Mohammed and her staff of the medical records department of Mubarak Al Khabeer Hospital for their assistance. 


\section{References}

1 Benatar SR: Fatal asthma. N Engl J Med 1986;314:423-429.

2 Wesserfallen JB, Schuller MD, Feihi $\mathrm{F}$, Perret $\mathrm{CH}$ : Sudden asphyxic asthma: A distinct entity? Am Rev Respir Dis 1990;142:108-111.

3 Picado C, Montserrat JM, Roca J, Rodriguez-Roisin R, Estopa $\mathrm{R}$, Xaubet A, Agusti-Vidal A: Mechanical ventilation in severe exacerbation of asthma. Eur J Respir Dis 1983;64:102-107.

4 Luksza AR, Smith P, Coackley J, Gordan IJ, Atherton ST: Acute severe asthma treated by mechanical ventilation: 10 years' experience from a district general hospital. Tho$\operatorname{rax} 1986 ; 41: 459-463$.

5 Scoggin CH, Sahn SA, Petty TL: Status asthmaticus: A nine year experience. JAMA 1977;238:1158-1162.

6 Westerman DE, Benatar SR, Potgieter $\mathrm{PD}$, Ferguson $\mathrm{AD}$ : Identification of the high risk asthmatic patient: Experience with 39 patients undergoing ventilation for status asthmaticus. Am J med 1979;66: 565-572.

7 Santiago SN, Klanstermeyer WB: Mortality in status asthmaticus: A nine-year experience in a respiratory intensive care unit. J Asthma Res 1980;17:75-79.

8 Braman SS, Kaemmerlen JT: Intensive care of status asthmaticus: A 10 year experience. JAMA 1990;264: 366-368.
9 Mountain RD, Sahn SA: Clinical features and outcome in patients with acute asthma presenting with hypercapnia. Am Rev Respir Dis 1988;138:535-539.

10 Lim TK: Status asthmaticus in medical intensive care. Singapore Med J 1989;30:334-338.

11 Marquette $\mathrm{CH}$, Saulnier F, Leroy O, Wallaert B, Chopin C, Demarq JM, Durocher A, Tonnel AB: Long term prognosis of near-fatal asthma: A 6year follow up study of 145 asthmatic patients who underwent mechanical ventilation for a near-fatal attack of asthma. Am Rev Respir Dis 1992;146:76-81.

12 Tuxen DV, Lane S: The effects of ventilatory pattern of hyperinflation, airway pressures, and circulation in mechanical ventilation of patients with severe airflow obstruction. Am Rev Respir Dis 1987;136: 872-879.

13 Tuxen DV: Detrimental effects of positive end-expiratory pressure during controlled mechanical ventilation of patients with severe airflow obstruction. Am Rev Respir Dis 1989;140:5-9.

14 Darioli R, Perret C: Mechanical controlled hyperventilation in status asthmaticus. Am Rev Respir Dis 1984;129:385-387.

15 Rosengarten P, Tuxen DV, Dziukas L, Scheinkestel C, Merret K, Bowes $\mathrm{G}$ : Circulatory arrest induced by intermittent positive pressure ventilation in a patient with severe asthma. Anaesth Intensive Care 1990;19: 118-121.
16 Williams TJ, Tuxen DV, Scheinkestel CD, Czarny D, Bowes G: Risk factors for morbidity in mechanically ventilated patients with acute severe asthma. Am Rev Respir Dis 1992;146:607-615.

17 Bellomo R, McLaughlin P, Tai E, Parkin G: Asthma requiring mechanical ventilation: A low morbidity approach. Chest 1994;103:891896.

18 Lee KH, Tan WC, Lim TK: Severe asthma. Singapore Med J 1997;38: 238-236.

19 American Thoracic Society. Standards for the diagnosis and treatment of COPD and asthma. Am Rev Respir Dis 1987;136:224-244.

20 Higgins R, Greening AR, Crompton GK: Assisted ventilation in severe acute asthma. Thorax 1986;41:464467.

21 Molfino NA, Nannini LJ, Mastelli AN, Slutsky AS: Respiratory arrest in near-fatal asthma. N Engl J Med 1991;324:285-288.

22 Rea HH, Scragg R, Jackson R, Beaglehole R, Fenwick J, Sutherland DC: A case-control study of deaths from asthma. Thorax 1986;41:833839 .

23 Barriot P, Riou B: Prevention of fatal asthma. Chest 1987;92:460466.

24 Williams NF, Crooke JW: The practical management of severe status asthmaticus. Lancet 1968;i:10811083.

25 Marchand P, Van Hesselt H: Last resort treatment of status asthmaticus. Lancet 1966;i:227-230. 